\title{
Kejadian mastitis subklinis pada kambing perah Peranakan Etawa di desa Bangelan kecamatan Wonosari kabupaten Malang
}

\section{Incidence of subclinical mastitis in Etawa crossbred goat in Bangelan village, Wonosari district, Malang regency}

\author{
Nur Zaini Nanda Mardian', Soeharsono Soeharsono², Nenny Harijani ${ }^{3}$, \\ Herry Agoes Hermadi ${ }^{4}$, Budiarto Budiarto ${ }^{3}$, Wurlina Wurlina ${ }^{4}$ \\ ${ }^{1}$ Mahasiswa, ${ }^{2}$ Departemen Anatomi, ${ }^{3}$ Departemen Kesehatan Masyarakat Veteriner, \\ ${ }^{4}$ Departemen Reproduksi, Fakultas Kedokteran Hewan, Universitas Airlangga \\ *Penulis koresponden, e-mail: nennyharijani@yahoo.co.id
}

Open access under CC BY - SA license, Doi : 10.20473/ovz.v9i3.2020.60-63

Received September 24 2020, Revised November 19 2020, Accepted November 222020

Published online December 62020

\begin{abstract}
Etawa crossbred goat is one species of goat that is raised for milk production. One of the diseases that often occur in dairy livestock is mastitis, in which there is inflammation of the mammary gland. It is common in goat, that mastitis does not show clinical symptoms (subclinical). This research aims to determine the incidence of subclinical mastitis in Etawa crossbred goats in Bangelan village Wonosari district Malang regency. This research involved 25 respondent farms, which are Etawa crossbred dairy goat farms. In this research, subclinical mastitis cases were directly detected using California Mastitis Test (CMT). The results showed that out of 70 samples collected, $41(58.6 \%)$ samples were positive. These CMT positive goats were from $88 \%$ of the respondent farms.
\end{abstract}

Keywords: California Mastitis Test, subclinical mastitis, Etawa crossbred goat

\section{PENDAHULUAN}

Kambing merupakan salah satu ternak yang berpotensi untuk dibudidayakan di Indonesia karena memiliki kemampuan adaptasi yang baik dan produktivitas yang tinggi dibanding ternak lain. Populasi kambing di Indonesia menurut data dari Direktorat Jenderal Peternakan dan Kesehatan Hewan tahun 2018 menunjukkan peningkatan dari 17.861.685 pada tahun 2016 menjadi 18.720.706 pada tahun 2018 (Ditjen PKH, 2018). Jenis kambing yang digemari masyarakat Indonesia salah satunya adalah kambing Peranakan Etawa (PE) karena dapat dimanfaatkan daging dan susunya. Kandungan protein dalam susu kambing lebih tinggi dibandingkan dengan susu sapi serta terdapat kandungan mineral, kalsium dan fosfor yang baik untuk tubuh (Suwito dan Indarjulianto, 2013). Susu kambing PE mengandung 3,86-
6,70\% protein, 2,52-6,20\% lemak, dan 9,5411,92\% Bahan Kering Tanpa Lemak (Zaidemarno et al., 2106). Kambing PE berpotensi untuk dijadikan sebagai kambing perah karena produksi susunya yang tinggi mencapai 1,5-3 liter dalam sehari (Ratya et al., 2018).

Masalah utama dalam usaha peternakan khusunya ternak perah adalah mastitis. Mastitis merupakan peradangan yang terjadi pada jaringan internal ambing yang disebabkan oleh infeksi mikroorganisme, zat kimia, luka termis (bakar) ataupun luka mekanis (Tewari, 2014). Kerugian akibat mastitis dapat berupa kerugian ekonomi akibat penurunan produksi susu. Mastitis dapat dibedakan berdasarkan ada tidaknya gejala, menjadi mastitis klinis dan subklinis. Mastitis klinis dapat diketahui secara langsung karena menunjukkan gejala peradangan seperti ambing bengkak, panas, 
sakit saat diraba dan terjadi perubahan pada susu yang dihasilkan (Artdita et al., 2020). Pada mastitis subklinis terjadi peningkatan jumlah sel somatik dalam susu tanpa disertai gejala dan perubahan fisik susu sehingga untuk mengetahui ternak yang menderita mastitis subklinis dibutuhkan metode tertentu (Suwito et al., 2013).

California Mastitis Test (CMT) merupakan salah satu metode yang telah banyak digunakan untuk mendeteksi mastitis subklinis secara langsung di lapangan. Kandungan dari reagen California Mastitis Test (CMT) yaitu alkyl aryl sulfonate $(3 \%)$, sodium hydroxide $(1,5 \%)$ dan bromocresol purple (1:10.000, sebagai indikator pH) (Iqbal et al., 2006). Cara kerja dari CMT yaitu mengamati reaksi antara reagen CMT yang mengandung arylsulfonate dengan sampel susu yang mengandung sel somatik dalam jumlah besar ketika terjadi peradangan, reaksi antara reagen dan leukosit akan membentuk masa gel atau lendir (Qolbaini et al., 2014).

Desa Bangelan kecamatan Wonosari kabupaten Malang merupakan salah satu sentra penghasil susu kambing di Jawa Timur. Masyarakat di sana biasanya menggunakan susu kambing untuk dikonsumsi maupun dijual secara komersial dalam bentuk segar maupun olahan. Hingga saat ini penelitian untuk mendeteksi kejadian mastitis subklinis di tempat tersebut belum pernah dilakukan.

\section{MATERI DAN METODE}

Penelitian ini menggunakan kambing PE laktasi dari 25 peternakan di wilayah desa Bangelan kecamatan Wonosari kabupaten Malang sebagai responden. Sampel yang digunakan pada penelitian ini adalah susu kambing segar yang diambil secara langsung dari peternakan responden. Sampling dilakukan secara purposive dengan kriteria kambing yang diambil sampelnya adalah (1) kambing yang aktif diperah, (2) kambing yang sudah diperah lebih dari 7 hari, dan (3) kambing yang tidak menunjukkan gejala mastitis klinis.

Pengambilan sampel susu dilakukan secara langsung oleh peternak dari ambing kambing secara aseptic. Sebelum dilakukan pemerahan ambing dibersihkan terlebih dahulu dengan cara dicuci dengan air bersih, lalu dikeringkan dengan kasa steril. Pancaran susu pertama dibuang kemudian pancaran susu selanjutnya ditampung sebanyak $3 \mathrm{ml}$ kedalam paddle tes untuk dilakukan uji menggunakan reagen CMT. Perbandingan sampel susu dengan reagen CMT yaitu 1:1. Paddle tes lalu dirotasikan secara horizontal selama 10 detik agar sampel susu dan reagen CMT tercampur homogen serta diamati perubahan konsistensi yang terjadi dengan cara memiringkan paddle tes sehingga dapat diamati perubahan konsistensi pada hasil positif. Pemeriksaan dilakukan pada kedua belah ambing kambing. Reaksi CMT negatif apabila tidak terjadi perubahan konsistensi dan sampel tidak menempel pada dasar paddle. Reaksi CMT positif, apabila terjadi perubahan konsistensi berupa pengentalan dan ketika paddle dimiringkan sampel yang mengental melekat pada dasar paddle.

\section{HASIL}

Interpretasi hasil CMT dilakukan secara visual dengan mengamati perubahan yang terjadi ketika dilakukan pemutaran secara horizontal pada paddle tes yang berisi campuran sampel susu dan reagen CMT berupa pengentalan, penggumpalan dan terbentuknya masa gel (Gambar 1).
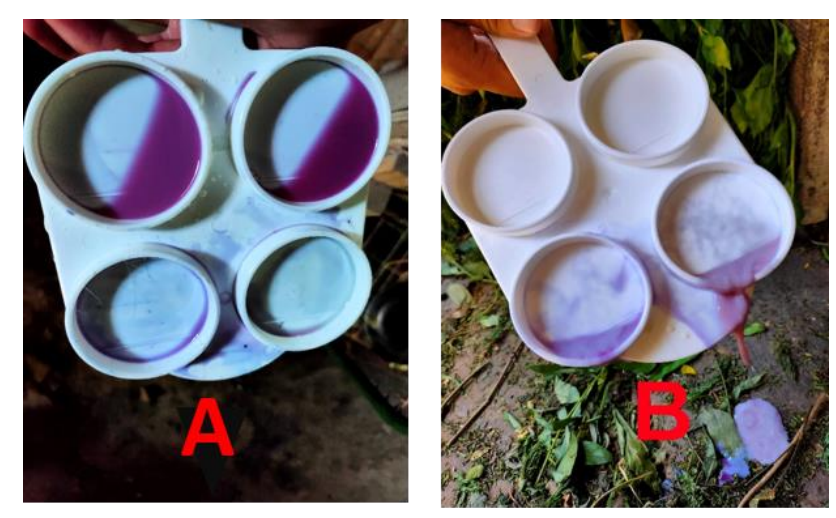

Gambar 1. Hasil California Mastitis Test (CMT); $\mathrm{A}=$ reaksi negatif, tidak terjadi perubahan konsistensi dan sampel tidak menempel pada dasar paddle; $\mathrm{B}=$ reaksi positif, terjadi perubahan konsistensi berupa pengentalan dan tampak sampel yang mengental melekat pada dasar paddle.

CMT yang dilakukan pada kedua belah ambing menunjukkan beberapa kambing yang positif mastitis subklinis hanya pada sebelah 
ambing saja. Kambing yang menunjukkan hasil tersebut dihitung sebagai hasil positif. Hasil penelitian menunjukkan bahwa dari 25 peternakan responden terdapat 22 peternakan (88\%) yang kambingnya positif mastitis subklinis. Pemeriksaan pada 25 peternakan menggunakan sampel susu kambing PE laktasi sebanyak 70 ekor menunjukkan 41 ekor $(58,6 \%)$ positif mastitis subklinis.

\section{PEMBAHASAN}

Hasil deteksi kasus Mastitis subklinis pada kambing PE pada penelitian ini menunjukkan 58,6\% kambing perah PE di desa Bangelan, Malang positif menderita Mastitis subklinis. Walaupun lebih rendah bila dibandingkan dengan angka kejadian pada peternakan kambing PE di kelurahan Kalipuro, Banyuwangi (82.76\%) (Sevitasari et al., 2019), namun tetap termasuk tinggi tingkat kejadiannya karena lebih dari 50\% kambing positif menderita mastitis subklinis, apalagi, kasus terjadi di $88 \%$ dari peternakan responden. Tingginya angka mastitis subklinis dapat disebabkan oleh berbagai faktor yang meliputi kondisi peternakan, kondisi ternak dan prosedur pemerahan (Nisa et al., 2019). Peternak di desa Bangelan melakukan pemerahan sehari-hari tidak di kandang khusus, namun secara langsung di kandang ternak tanpa pembersihan dan pemisahan dari ternak yang lain terlebih dahulu. Hal ini berpotensi untuk terjadinya penularan yang berasal dari lantai kandang yang kotor. Bakteri penyebab mastitis dapat ditularkan dari lantai kandang yang kotor, mesin perah, lap, baju pemerah dan dari puting terinfeksi ke puting sehat melalui tangan pemerah (Fatmawati et al., 2019). Penularan juga dapat terjadi dari ternak yang sakit ke ternak sehat melalui tangan pemerah. Pemerahan menggunakan tangan yang kurang bersih berpotensi menularkan bakteri penyebab mastitis ke ternak yang lain. Air untuk mencuci ambing juga merupakan sumber Pseudomonas sp. penyebab mastitis klinis pada kambing PE (Suwito et al., 2013). Beberapa faktor resiko terjadinya kasus mastitis subklinis pada kambing PE telah diidentifikasi. Produksi susu yang tinggi pada masing-masing kambing berkorelasi dengan kejadian mastitis subklinis, kambing yang berumur tua lebih rentan terhadap infeksi bakteri dibandingakan dengan yang berumur muda, umur menyapih lebih dini lebih berisiko, dan Body Condition Score 3,03,5 rentan terhadap mastitis subklinis karena produksi susu per ekor kambing lebih tinggi dari rata-ratanya (Suwito et al., 2014).

Upaya yang dapat dilakukan untuk mengurangi kejadian mastitis subklinis pada ternak antara lain dengan memperhatikan manajemen pemerahan dan perkandangan, pembersihan puting sebelum diperah dan melakukan teat dipping pasca pemerahan menggunakan antiseptik. Hal ini disebabkan pada kambing PE penderita mastitis subklinis terdapat bakteri Bacillus sp, Staphylococcus sp, Streptococcus sp, Corynebacterium sp, Pseudomonas $\mathrm{sp}$, dan E. coli (Suwito et al., 2014). Hasil deteksi bakteri pada susu positif mastitis subklinis di kecamatan Kokap (Artdita et al., 2020) menunjukkan dua jenis bakteri Gram positif (Staphylococcus aureus 80\%, Staphylococcus epidermidis 20\%), dan dua jenis bakteri Gram negatif (Escherichia coli $10 \%$, Klebsiella pneumoniae $10 \%$ ). Isolasi dan identifikasi staphylococcus aureus pada susu kambing PE penderita mastitis subklinis di kelurahan Kalipuro, Banyuwangi menunjukkan 94,1\% sampel positif Staphylococcus aureus (Hayati et al., 2019).

\section{KESIMPULAN}

Berdasarkan penelitian yang telah dilakukan di 25 peternakan kambing perah PE di desa Bangelan kecamatan Wonosari kabupaten Malang didapatkan kasus positif mastitis subklinis pada $88 \%$ peternakan responden, yang meliputi $58,57 \%$ kambing Peranakan Etawa laktasi.

\section{DAFTAR PUSTAKA}

Artdita CA, Andityas M, Prihanani NI, Budiyanto YW. 2020. Deteksi bakteri penyebab mastitis subklinis pada kambing Peranakan Etawah di Kokap, Kulon Progo, Daerah Istimewa Yogyakarta. J Sain Veteriner 38: 37-44.

Direktorat Jenderal Peternakan dan Kesehatan Hewan (Ditjen PKH). 2018. Statistik Peternakan dan Kesehatan Hewan. Kementerian Pertanian RI. Jakarta. 80-82. 
Fatmawati M, Setianingrum A, Haskito AEP, Dameanti FNAEP. 2019. Prevalensi dan faktor predisposisi mastitis subklinis pada sapi perah rakyat dusun Bakir, desa Sukomulyo, kabupaten Batu. Vet Biomed Clin J. 1: 35-41.

Hayati LN, Tyasningsih W, Praja RN, Chusniati S, Yunita MN, Wibawati PA. 2019. Isolasi dan identifikasi staphylococcus aureus pada susu kambing Peranakan Etawah penderita mastitis subklinis di kelurahan Kalipuro, Banyuwangi. J Medik Veteriner 2:76-82.

Iqbal M, Amjed M, Khan MA, Kureshi MS, Sadique U. 2006. comparative efficiency of some indirect diagnostic tests for the detection of sub-clinical mastitis in cows and buffaloes. Pakistan Vet J 26: 73-9.

Nisa HC, Sunardirahardjo BP, Lestari TD, Hariadi M, Sidik R, Harijani N. 2019. Analisis faktor yang mempengaruhi kejadian mastitis subklinis dan klinis pada sapi perah. Ovozoa J Anim Reprod 8: 6670.

Qolbaini EN, Artika IM, Safari D. 2014. Detection of subclinical mastitis in dairy cows using California Mastitis Test and Udder Pathogen. Curr Biochem 1: 66-70.

Ratya N, Taufik E, Arief II. 2018. Karakteristik kimia, fisik dan mikrobiologis susu kambing Peranakan Etawa di Bogor. J Ilmu
Produksi dan Teknologi Hasil Peternakan 5: $1-4$.

Sevitasari AP, Effendi MH, Wibawati PA. Deteksi mastitis subklinis pada kambing Peranakan Etawah di kelurahan Kalipuro, Banyuwangi. J Medik Veteriner 2: 72-5.

Suwito W, Nugroho WS, Sumiarto B, Wahyuni AETH. 2014. Faktor-faktor risiko mastitis subklinis pada kambing Peranakan Etawah di Kabupaten Sleman, Yogyakarta. J Veteriner 15: 130-8.

Suwito W, Wahyuni AETH, Nugroho WS, Sumiarto B. 2013. Isolasi dan Identifikasi Bakteria Mastitis Klinis pada Kambing Peranakan Ettawah. J Sain Veteriner 31: 49-54.

Suwito W, Indarjulianto S. 2013. Staphylococcus aureus penyebab mastitis pada kambing Peranakan Etawa: epidemiologi, sifat klinis, patogenesis, diagnosis dan pengendalian. Wartazoa 23: 1-7.

Tewari A. 2014. Bovine mastitis: An important dairy cattle disease. Indian Dairyman. 62-5.

Zaidemarno N, Husni A, Sulastri S. 2016. Kualitas kimia susu kambing Peranakan Etawa pada berbagai periode laktasi di desa Sungai Langka kecamatan Gedong Tataan kabupaten Pesawaran. J Ilmiah Peternakan Terpadu 4: 307-12. 